\title{
Effect of chlormequat chloride, $\beta$-naphthoxyacetic acid and ethephon on early and total yield of tomato in open field
}

\author{
JAN BORKOWSKI and LESZEK S. JANKIEWICZ
}

Research Institute of Vegetable Crops, ul. 22 Lipca 1/3, 96-100 Skierniewice, Poland

(Received: April 29, 1981)

\begin{abstract}
Tomato seedlings in hotbed with Antywylegacz (chlormequat chloride) to suppress their excessive elongation before transplanting, were used. Their first $2-3$ flower clusters were dipped in the field in Betokson ( $\beta$-naphthoxyacetic acid) to induce better early fruit set and the plants were sprayed with Ethrel (ethephon) just before the first fruits become pink, to stimulate earlier ripening and increase early yield. The experiment was carried out during 3 years with the cultivars 'Venture', 'New Yorker' and 'Nesthäckchen' (only in 1975). Application of chlormequat alone prevented excessive growth of the seedlings but did not increase early yield significantly. $\beta$-naphthoxyacetic acid alone was effective every year and always increased early yield. Chlormequat followed by $\beta$-naphthoxyacetic treatment showed always a tendency to increase early yield more than $\beta$-naphthoxyacetic acid alone. Treatment with $\beta$-naphthoxyacetic acid, alone or in combination with other treatments, lowered the total yield. Ethephon used solely or in combination with other treatments usually was ineffective.
\end{abstract}

\section{INTRODUCTION}

There are 3 chemicals considered to increase early yield of tomato plants: Antywylegacz (chlormequat chloride), Betokson and Ethrel. Spraying young plants with chlormequat chloride in a hotbed makes the plants grow more compactly so that they suffer less from drought and frost after transplantation. They often give higher early yields ( $\mathrm{M}$ i s $\mathrm{h}$ a $\mathrm{r}$ a and $\mathrm{Pr}$ a d h a $\mathrm{n}$, 1972; Le d ov s k i, 1974, 1977; B or k ow s k i, 1975, 1976; B o r k ow s k i and $\mathrm{J}$ a g o d a, 1977; S h u $1 \mathrm{~g}$ i n a, 1977; C a s t r o and $\mathrm{M}$ a 1 a volt a, 1977; P is a r c z y and S p lit t s o e s s e r, 1979).

Dipping in or spraying the clusters with $\beta$-naphthoxyacetic acid (Betokson) induces parthenocarpy or stimulates the growth of fruits which then contain a smaller than usual number of seeds. Since fruit set of the first $2-3$ clusters is normally very poor in Poland, Betokson usually improves the yield in the field. 
This growth regulator has been widely used in Poland for 20 years, mostly in greenhouses ( $\mathrm{K}$ e p k o w a, 1959, 1968; $\mathrm{K}$ e p k o w a and $\mathrm{G} \mathrm{r}$ a j e ws k a, 1972).

Treatment of the plants with ethephon at the time when the fruits in the first 2- 3 clusters almost reach their final size and some of them start to change their colour from white to pink accelerates their ripening (I $\mathrm{w}$ a $\mathrm{h}$ or i and L y o n s, 1970; C h r o m i ń s k , 1971; S i m s, 1969; $\mathrm{S}$ i m s and K a s h m i e, 1972; B or k ow sk i, 1976).

The aim of the present investigation was to check if the early yield tomatoes cultivated in the open may be increased more by these joint treatments than by a single one.

\section{MATERIAL AND METHODS}

The experiment was carried out for 3 years in Skierniewice on sandy loam podsolic soil with organic matter content $1-1.2 \%$ and $\mathrm{pH}\left(\mathrm{H}_{2} \mathrm{O}\right)$ about 6 . The following cultivars were used: 'Venture' (for 3 years), 'Nesthäckchen' (only in 1975) and 'New Yorker' (in 1976 and 1977). Each year the tomatoes were planted in a field which had been manured in the previous year or 2 years earlier. Spring fertilization per 1 ha was as follows each year: $200 \mathrm{~kg} \mathrm{~K}$ (as $\mathrm{K}_{2} \mathrm{SO}_{4}$ ), $44 \mathrm{~kg} \mathrm{P}$ (as superphosphate), $120 \mathrm{~kg} \mathrm{~N}$ (as $\mathrm{NH}_{4} \mathrm{NO}_{3}$ ). Half of the nitrogen was given before planting and half after planting (Table 1).

The dates of sowing, planting and other treatments are shown in Table 1.

Table 1

Time table of operations

\begin{tabular}{lrlrl}
\hline Specification of operations & \multicolumn{1}{c}{1975} & \multicolumn{1}{c}{1976} & 1977 \\
\hline Sowing & 19 March & 22 March, 1 April* & 22 March \\
Transplantation & 16 April & 9 April & 14 and 15 April \\
Treatment with Antywylegacz & 7 and 16 May & 6 and 15 May & 2 and 10 May \\
Planting in the field & 21 May & 18 May & 16 May \\
Treatment with Betokson & 11 and 19 June & 7,15 and 21 June & 11 and 22 June \\
Ethrel spray & 16 July & 3 August & 5 August \\
Top dressing with nitrogen & 18 June & 16 June & 25 June \\
First harvest & 18 July & 16 July** & 27 July \\
Early yield harvested up, to & 6 August & 16 August & 19 August \\
Last harvest & 17 September & 16 September & 12 September \\
\hline
\end{tabular}

*The seeds of cv. 'New Yorker' were sown on 1 April because the seeds sown previously failed to germinate.

** Almost all earliest fruits of cv. 'New Yorker' were on the plots treated with Betokson affected with blossom-end rot in this particular year. 
The fruits were harvested about 10 times in the season at intervals of about 5 8 days, they were divided into:

1st quality grade: diameter larger than $4 \mathrm{~cm}$, normal shape, healthy, not cracked;

2nd quality grade: diameter $3-4 \mathrm{~cm}$, healthy, fruits with healed crackings, of diameter $\geqslant 3 \mathrm{~cm}$;

freshly cracked fruits irrespective of their size;

small, healthy fruits, $<3 \mathrm{~cm}$;

diseased fruits irrespective of size.

Early yield was the sum of the first 4 harvests without diseased fruits. Growth regulators namely: Antywylegacz ( $98 \%$ of chlormequat chloride) and Betokson $(1 \%$ of $\beta$-naphthoxyacetic acid) were of Polish production. Ethrel $(48 \%$ of ethephton) was received from Union Carbide, USA. Control plants were not sprayed.

Chlormequat chloride in $125 \mathrm{mg} / \mathrm{l}$ conc. of active constituent was used twice an abundant spray amounted to $21 / \mathrm{m}^{2}$ for young plants in hotbed the first time when the fourth leaf appeared, and the second about 10 days later but at a least a few days before transplanting. Betokson in a $5 \mathrm{ml} / 1 \mathrm{H}_{2} \mathrm{O}$ conc. was used by dipping the first and the second clusters when half of their flowers were developed. Spraying the clusters with Ethrel $1 \mathrm{ml} / 1 \mathrm{H}_{2} \mathrm{O}$ was applied once, when the first fruits in the first clusters in the field started to become pink.

To learn how much fresh and dry matter was accumulated in the fruits and in the vegetative, above-ground parts, the plants were divided into these two components and their fresh and dry matter was estimated (drying at $60^{\circ} \mathrm{C}$ ). This comparison was done in 1975 with control and Betokson-treated plants.

The experiment was designed in 4 randomized blocks with 20 plants per plot. The results were elaborated by analysis of variance with Student's t-test for significance at $\alpha=0.05$.

\section{RESULTS}

The effect of Antywylegacz (chlormequat chloride) on the height of transplants was measured just before planting them into the field. The transplants treated with Antywylegacz alone were each year 30-53\% smaller than controls (Table 2). If the plants treated with Antywylegacz met with hot and dry weather after being transplanted, they developed better than the controls.

The effect of Antywylegacz on early yield was not significant with all cultivars investigated. Betokson increased the early yield of cv. 'Venture' plants about $2.1-46.2$ times above that of the control in dependence on year (Table 3). With the cv. 'Nesthäckchen' or 'New Yorker' this effect was less pronounced (Table 4).

Ethrel alone was applied only in one year (1977). Its effect on early yield was insignificant. 
Tab le 2

Height of plants before transplantation (in $\mathrm{cm}$ )

Averages from 25 plants

\begin{tabular}{lccccc}
\hline Treatment & $\begin{array}{c}\text { 'Venture' } \\
\text { agregates for } \\
\text { years } \\
1975-77\end{array}$ & $\begin{array}{c}\text { 'Nesthäck- } \\
\text { chen' } \\
1975\end{array}$ & \multicolumn{2}{c}{ 'New Yorker' } \\
\cline { 4 - 5 } & 36.0 & 39.8 & 1976 & 1977 \\
\hline $\begin{array}{l}\text { Control } \\
\text { Anty wylegacz } \\
125 \mathrm{mg} / \mathrm{l}\end{array}$ & 20.0 & 23.0 & 13.6 & 37.6 \\
\hline
\end{tabular}

Application of 2 different treatments on the same plants revealed that Betokson applied after Antywylegacz showed a tendency to increase early yield more than Betokson alone. This difference was significant with cv. 'Nesthäckchen'. Application of Betokson and Ethrel on the same plants usually caused a similar early yield, as application of Betokson alone (significant difference with Betokson alone was observed only with cv. 'New Yorker' in 1977). Application of Antywylegacz and Ethrel on the same plants did not cause better cropping than Antywylegacz alone. Application of all 3 treatments to the same plants caused often the highest early yield but it was never significantly higher than in plants treated with Antywylegacz and Betokson. The per cent of marketable fruits in early crop was very high in all years (80-95\%), only in 1976 there were $54-65 \%$ of marketable fruits from control plants.

Table 3

Influence of Antywylegacz, Betokson and Ethrel on early yield in the years 1975-1977 cv. 'Venture'

\begin{tabular}{|c|c|c|c|c|}
\hline \multirow[b]{2}{*}{ Treatment } & \multicolumn{4}{|c|}{ Early marketable yield $\mathrm{kg} / 100 \mathrm{~m}^{2}$} \\
\hline & $\begin{array}{c}1975 \\
\text { August } \\
6\end{array}$ & $\begin{array}{c}1976 \\
\text { August } \\
16\end{array}$ & $\begin{array}{c}1977 \\
\text { August } \\
19\end{array}$ & average \\
\hline Control plants & $27.0 \mathrm{a}$ & $1.8 \mathrm{a}$ & $36.7 \mathrm{ab}$ & $21.8 \mathrm{a}$ \\
\hline Anty wylegacz $125 \mathrm{mg} / \mathrm{l}$ & $46.4 \mathrm{ab}$ & $8.7 \mathrm{ab}$ & $33.2 \mathrm{a}$ & $30.4 \mathrm{a}$ \\
\hline $\begin{array}{l}\text { Betokson } 5 \mathrm{~cm}^{3} / 1^{*} \\
\text { Ethrel } 1 \mathrm{~cm}^{3} / 1\end{array}$ & $107.7 \mathrm{de}$ & $83.2 \mathrm{c}$ & $\begin{array}{l}77.1 \mathrm{~cd} \\
63.8 \mathrm{bc}\end{array}$ & $89.3 \mathrm{~b}$ \\
\hline $\begin{array}{l}\text { Anty wylegacz } 125 \mathrm{ml} / 1+ \\
+ \text { Betokson } 5 \mathrm{~cm}^{3} / 1 \\
\text { Antywylegacz } 125 \mathrm{ml}^{2}+\end{array}$ & 132.2 ef & $86.9 \mathrm{c}$ & $100.3 \mathrm{de}$ & $106.5 \mathrm{bc}$ \\
\hline+ Ethrel $1 \mathrm{~cm}^{3} / 1$ & $70.7 \mathrm{bc}$ & $17.8 \mathrm{~b}$ & $46.2 \mathrm{ab}$ & 44.9 a \\
\hline $\begin{array}{l}\text { Betokson } 5 \mathrm{~cm}^{3} / 1+\text { Ethrel } 1 \mathrm{~cm}^{3} / 1 \\
\text { Antywylegacz } 125 \mathrm{mg} / \mathrm{l}+\text { Ethrel }\end{array}$ & $89.9 \mathrm{~cd}$ & $93.3 \mathrm{c}$ & $101.9 \mathrm{de}$ & $95.0 \mathrm{bc}$ \\
\hline $1 \mathrm{~cm}^{3} / 1+$ Betokson $5 \mathrm{~cm}^{3} / 1$ & $148.1 \mathrm{f}$ & $85,7 \mathrm{c}$ & $119.8 \mathrm{e}$ & $117.9 \mathrm{c}$ \\
\hline
\end{tabular}

*Equivalent to $50 \mathrm{mg} / 1$ of $\beta$-naphthoxyacetic acid. 
T a b l e 4

The influence of Antywylegacz, Betokson and Ethephon on the early yield of cv. 'Nesthäckchen' (N) (only in 1975), cv. ' New Yorker' (NY)

(in 1976 and 1977)

\begin{tabular}{|c|c|c|c|}
\hline \multirow{3}{*}{ Treatment } & \multicolumn{3}{|c|}{$\begin{array}{l}\text { Early marketable yield } \\
\qquad\left(\mathrm{kg} / 100 \mathrm{~m}^{2}\right)\end{array}$} \\
\hline & \multirow{2}{*}{$\frac{N}{1975}$} & \multicolumn{2}{|c|}{ NY } \\
\hline & & 1976 & 1977 \\
\hline Control & $54.0 \mathrm{a}$ & $6.4 \mathrm{a}$ & $41.9 \mathrm{a}$ \\
\hline Antywy legacz $125 \mathrm{mg} / 1$ & $85.1 \mathrm{~b}$ & $10.0 \mathrm{a}$ & $39.0 \mathrm{a}$ \\
\hline Betokson $5 \mathrm{~cm}^{3} / 1$ & $90.2 \mathrm{~b}$ & $49.1 \mathrm{~b}$ & $50.8 \mathrm{ab}$ \\
\hline Ethrel $1 \mathrm{~cm}^{3} / 1$ & - & - & $64.0 \mathrm{abc}$ \\
\hline Antywy legacz + Betokson* & $145.3 \mathrm{c}$ & $53.5 \mathrm{~b}$ & $75.7 \mathrm{bc}$ \\
\hline Antywy legacz + Ethrel* & $93.3 \mathrm{~b}$ & $16.9 \mathrm{a}$ & $51.2 \mathrm{ab}$ \\
\hline Betokson + Ethrel* & $103.2 \mathrm{~b}$ & $52.2 \mathrm{~b}$ & $93.2 \mathrm{c}$ \\
\hline $\begin{array}{l}\text { Antywylegacz }+ \text { Betokson }+ \\
\quad+\text { Ethrel }^{*}\end{array}$ & $157.8 \mathrm{c}$ & $50.4 \mathrm{~b}$ & $90.5 \mathrm{c}$ \\
\hline
\end{tabular}

${ }^{*}$ Concentration of chemicals is the same as in Table 3.

$\mathrm{Cv}$. 'Venture' gave in each year a significantly higher marketable yield $\left(50-150 \mathrm{~kg} / 100 \mathrm{~m}^{2}\right)$ than the cultivar 'Nesthäckchen' or 'New Yorker' (Tables 5 , 6). Every year marketable yields were the highest for the treatments: control, Antywylegacz alone and plus Ethrel as it was usually for total yields.

The lowest marketable yield was obtained from plots treated with Betokson. The same effect was observed in the total yield. The response of all cultivars to those treatments was similar. The total yield from plants treated with Betokson alone or Betokson in combination with other treatments was usually lower than that from control plants. Treatments not including Betokson did not decrease the total yield. These results indicate that the Betokson-induced increase of early yield causes a concomitant decrease of the late yield. To check if this phenomenon is caused by competition between vegetative growth and formation of early fruits, the fresh and dry mass of the fruits and vegetative above-ground parts of the plants was compared on July 12th, i.e. at the time when the first fruits were set on the control plants (Table 7). The plants treated with Betokson alone developed heavy early yield amounting to $41-58 \%$ of the total dry mass of the above-ground part of the plant. In control plants early yield amounted to as little as $6-7 \%$ of the whole plant dry mass. In spite of that there was no significant difference between the total dry mass of whole plants (with fruits) treated with Betokson and of control plants. (Table 7). This result strongly suggests that the high early yield in Betokson-treated plants formed at the expense of vegetative growth of the plants during early summer. This must inevitably decrease the ability of the plants to form fruits during the second half of the vegetation season. 
Table 5

Influence of Antywylegacz, Betokson and Ethephon on the marketable and total yield in the years 1975-1977 cv. 'Venture'

\begin{tabular}{|c|c|c|c|c|c|c|c|c|}
\hline \multirow{2}{*}{ Treatment } & \multicolumn{4}{|c|}{ Marketable yield $\mathrm{kg} / 100 \mathrm{~m}^{2}$} & \multicolumn{4}{|c|}{ Total yield $\mathrm{kg} / 100 \mathrm{~m}^{2}$} \\
\hline & 1975 & 1976 & 1977 & average & 1975 & 1976 & 1977 & average \\
\hline Control plants & $433.3 \mathrm{bc}$ & $473.4 \mathrm{c}$ & $218.6 \mathrm{ab}$ & $375.1 \mathrm{~b}$ & $596.6 \mathrm{c}$ & $551.2 \mathrm{~d}$ & $408.1 \mathrm{bc}$ & $518.6 \mathrm{c}$ \\
\hline Antywylegacz $125 \mathrm{mg} / \mathrm{l}$ & $476.4 \mathrm{c}$ & $417.1 \mathrm{bc}$ & $181.4 \mathrm{a}$ & $358.3 \mathrm{ab}$ & $592.0 \mathrm{c}$ & $496.7 \mathrm{c}$ & $303.5 \mathrm{ab}$ & $464.1 \mathrm{bc}$ \\
\hline $\begin{array}{l}\text { Betokson } 5 \mathrm{~cm}^{3} / 1 \\
\text { Ethrel } 1 \mathrm{~cm}^{3} / 1\end{array}$ & $431.0 \mathrm{bc}$ & $295.3 \mathrm{a}$ & $\begin{array}{l}165.9 \mathrm{a} \\
208.6 \mathrm{ab}\end{array}$ & 297.4 a & $548.0 \mathrm{bc}$ & 357.9 a & $\begin{array}{l}258.5 \mathrm{ab} \\
338.9 \mathrm{abc}\end{array}$ & 388.1 a \\
\hline Betokson + Ethrel ${ }^{*}$ & $354.6 \mathrm{a}$ & $350.2 \mathrm{ab}$ & $206.9 \mathrm{ab}$ & $303.9 \mathrm{ab}$ & 427.7 a & $415.8 \mathrm{abc}$ & $328.0 \mathrm{abc}$ & $390.5 \mathrm{ab}$ \\
\hline Antywylegacz + Ethrel + Betokson* & $410.8 \mathrm{ab}$ & $275.9 \mathrm{a}$ & $208.0 \mathrm{ab}$ & $298.2 \mathrm{a}$ & $490.2 \mathrm{ab}$ & $341.5 \mathrm{a}$ & $285.2 \mathrm{a}$ & $372.3 \mathrm{a}$ \\
\hline
\end{tabular}

${ }^{*}$ Concentration of chemicals is the same as in Table 3.

Table 6

Influence of various treatments on the yield and its structure cv. 'Nesthäckchen' (N), (only in 1975), cv. 'New Yorker' (NY) (in 1976 and 1977)

\begin{tabular}{|c|c|c|c|c|c|c|}
\hline \multirow{3}{*}{ Treatment } & \multicolumn{3}{|c|}{ Marketable yield $\left(\mathrm{kg} / 100 \mathrm{~m}^{2}\right)$} & \multicolumn{3}{|c|}{ Total yield $\left(\mathrm{kg} / 100 \mathrm{~m}^{2}\right)$} \\
\hline & \multirow{2}{*}{$\frac{N}{1975}$} & \multicolumn{2}{|c|}{ NY } & \multirow{2}{*}{$\frac{\mathrm{N}}{1975}$} & \multicolumn{2}{|c|}{ NY } \\
\hline & & 1976 & 1977 & & 1976 & 1977 \\
\hline Control & $303.4 \mathrm{bc}$ & $309.6 \mathrm{~b}$ & $199.3 \mathrm{bc}$ & $400.5 \mathrm{bc}$ & $378.4 \mathrm{~b}$ & $302.1 \mathrm{~b}$ \\
\hline Antywylegacz $125 \mathrm{ml} / \mathrm{l}$ & $312.4 \mathrm{bc}$ & $310.0 \mathrm{~b}$ & $199.0 \mathrm{bc}$ & $411.1 \mathrm{c}$ & $269.9 \mathrm{~b}$ & $292.1 \mathrm{~b}$ \\
\hline Betokson $5 \mathrm{~cm}^{3} / 1$ & $192.0 \mathrm{a}$ & $163.3 \mathrm{a}$ & $1099 \mathrm{a}$ & 246.1 a & $200.3 \mathrm{a}$ & $152.6 \mathrm{a}$ \\
\hline Ethrel $1 \mathrm{~cm}^{3} / 1$ & - & - & $228.9 \mathrm{c}$ & - & - & $317.0 \mathrm{~b}$ \\
\hline Antywylegacz + Betokson* & $256.4 \mathrm{ab}$ & 139.4 a & $129.5 \mathrm{ab}$ & $318.9 \mathrm{ab}$ & $170.6 \mathrm{a}$ & $235.2 \mathrm{ab}$ \\
\hline Antywylegacz + Ethrel* & $346.1 \mathrm{c}$ & 316.9 a & $213.1 \mathrm{bc}$ & $443.5 \mathrm{c}$ & $383.1 \mathrm{~b}$ & $299.3 \mathrm{~b}$ \\
\hline Betokson + Ethrel* & $259.5 \mathrm{ab}$ & 166.5 a & $170.6 \mathrm{abc}$ & $323.7 \mathrm{ab}$ & 205.2 a & $233.6 \mathrm{ab}$ \\
\hline Antywylegacz + Ethrel + Betokson & $235.7 \mathrm{ab}$ & $166.5 \mathrm{a}$ & $115.4 \mathrm{a}$ & $295.1 \mathrm{a}$ & $202.4 \mathrm{a}$ & $170.3 \mathrm{a}$ \\
\hline
\end{tabular}

*Concentration of chemicals is the same as in Table 3 . 
The amount of cracked and small fruits on plants variously treated did not differ markedly, the differences were wider between years and cultivars. A similar situation concerns the weight of diseased fruits. For instance in the summer 1977 in which the weather was cold the incidence of fungal diseases was high. It was found in that year that cv. 'New Yorker' is more resistant to late blight (Ph. infestans) than cv. 'Venture'. In 1977 the amount of diseased fruits in the total yield was higher in control plants than in those treated with Betokson alone or Betokson combined with other treatments. This probably resulted from the fact that the early yield, which is normally healthier in Polish conditions than the late one had a larger share in the total yield of Betokson-treated plants.

\section{T a b le 7}

Influence of Betokson on fruit set and on growth of vegetative (above-ground) parts of the plant. Measurements on July 12th 1976 when the fruits of the treated plants were almost fully grown

\begin{tabular}{|c|c|c|c|c|c|c|c|}
\hline \multirow[b]{2}{*}{$\begin{array}{l}\text { Treatment and } \\
\text { cultivar }\end{array}$} & \multicolumn{2}{|c|}{ Fresh matter (in g) } & \multirow{2}{*}{$\begin{array}{c}\text { Share of } \\
\text { fruits }(\%) \\
\text { in fresh } \\
\text { matter of } \\
\text { whole plant }\end{array}$} & \multicolumn{2}{|c|}{ Dry matter (in $\mathrm{g}$ ) } & \multirow{2}{*}{$\begin{array}{c}\text { Share of } \\
\text { fruits }(\%) \\
\text { in dry } \\
\text { matter of } \\
\text { whole plant }\end{array}$} & \multirow{2}{*}{$\begin{array}{l}\text { Diameter } \\
\text { of } 1 \text { plant } \\
\text { (in } \mathrm{cm} \text { ) on } \\
\text { August } 19 \text { th }\end{array}$} \\
\hline & $\begin{array}{c}\text { plants } \\
\text { without } \\
\text { fruits }\end{array}$ & fruits & & $\begin{array}{c}\text { plants } \\
\text { without } \\
\text { fruits }\end{array}$ & fruits & & \\
\hline
\end{tabular}

'Venture'

Control

9.5

$38.0 \mathrm{c}$

2.6 a

6.4

$21.7 \mathrm{~b} \quad 15.1 \mathrm{~b}$

41.0

73.5

Betokson $5 \mathrm{~cm}^{3} / 1 \quad 137$

$196 \mathrm{~b} \quad 58.8$

'New Yorker'

Control

$169 \mathrm{~b} \quad 22 \mathrm{a}$

11.5

$27.7 \mathrm{~b}$

$2.0 \mathrm{a}$

6.7

11.2 a 15.4 b

58.1

56.4

Betokson $5 \mathrm{~cm}^{3} / 1$

70 a $170 \mathrm{~b}$

70.8

\section{DISCUSSION}

Among 3 substances used in this experiment to increase early yield of tomato, only Betokson ( $\beta$-naphthoxyacetic acid) was effective every year. It increased early yield over that of controls on the average about 3 times. Since the years with long periods of wet and cold weather during summer, are quite common recently in Poland, the tomato plants were attacked by Phytophthora infestans and a large proportion of the late crop was usually lost. In such conditions application of Betokson in field production seems to be very profitable ( $G$ ó r e c k a and J a n k i e w i c z, 1980). The increase of early crops in this experiment owing to Betokson was comparable to that in other experiments ( $\mathrm{K}$ ę p k o w a, 1959,1968; G ó r e c k a and J a n k i e w i c z, 1980). The cause of the relatively low effect of Betokson in 1977 could be due to the late application of additional nitrogen fertilization after heavy rains which had leached a large proportion of $\mathrm{N}$, so that symptoms of $\mathrm{N}$-deficiency became already visible on plants. 
The effect of Antywylegacz (chlormequat chloride) depended to great extent on the weather in the period just after planting the transplants into the field. Nevertheless Antywylegacz inhibited growth of the aerial part and stimulated that of the roots. The plants were shorter and stiffer and, therefore, more suitable for mechanized planting, as shown by $\mathrm{B}$ or k o w s k i and $\mathrm{J}$ a $\mathrm{g} \mathrm{o} \mathrm{d} \mathrm{a}$ (1977). O s t r z y c k a and B o r k ow s k i (1982), showed that the residue of chlormequat in fruits harvested from plants treated with Antywylegacz in a concentration of $125 \mathrm{mg} / \mathrm{l}$ is very small - below $0.1 \mathrm{mg} / \mathrm{kg}$ fresh wt. Antywylegacz and Betokson used on the same plants showed a tendency to increase the early crop in comparison with the use of Betokson alone. Since it is possible that it will be allowed to apply these two treatments on the same plants, these results may be of practical importance.

Ethrel (ethephon) applied alone on plants treated previously with other growth regulators usually did not increase the early crop. This may indicate that this treatment does not give satisfactory promotion of early yielding in field grown tomatoes in our country. Probably too low summer temperature for ethephon activity is the cause of this (B u s s e 1, 1973). Ethephon is, however, effective in greenhouses, where the temperature is sufficiently higher ( $\mathrm{S} \mathrm{i} \mathrm{m} \mathrm{s}$, 1969). It is not necessary to use the 3 mentioned compounds on the same plants: such plants do not give a significantly higher early yield than those treated only with chlormequat chloride and $\beta$-naphthoxyacetic acid, whereas the expense of 3 treatments is higher than when only chlormequat chloride plus $\beta$-naphthoxyacetic acid are applied.

\section{REFERENCES}

B ork ow ski J., 1975. Wpływ CCC, B $_{995}$ i Ethrelu na wzrost, kwitnienie i owocowanie pomidorów. [Effect of $\mathrm{CCC}, \mathrm{B}_{995}$ (Alar) and Ethrel on tomato growth and development]. Ogrodnictwo 2: 40-41.

B o r k o w s k i J., 1976. Wpływ retardantów, TIBA i Ethrelu na wzrost, kwitnienie i owocowanie pomidorów. [The influence of retardants, TIBA and Ethrel on the growth, flowering and fruiting of tomatoes in field cultivation]. Biul. Warz. 19: 313-327.

B o r k ow s k i J., J a g o d a J., 1977. Traktowanie rozsady pomidorów w inspekcie roztworem $\mathrm{CCC}$ w celu ulatwienia mechanicznego sadzenia. [The use of $\mathrm{CCC}$ on tomato seedlings grown in hotbed makes mechanical planting easier]. Ogrodnictwo 12: 312.

B u s s e 11 W. T., 1973. Effects of ethephon (Ethrel 48) on outdoor late stoked tomatoes. New Zealand J. Exp. Agr. 1: 123 - 125.

C a s t r o P. R. C., M a lavolt a E., 1977. Influence of growth regulators upon mineral nutrition, osmotic potential and incidence of blossom-end rot of tomato. Turrialba 27, 3: 273 $-276$.

C h r o m i ń s k i A., 1971. Stan badań nad zastosowaniem kwasu 2-chloroetylofosfonowego w przyśpieszeniu dojrzewania owoców pomidorów. Post. Nauk Rol. 5: 91 - 110.

G ó r e c k a K., J a n k i e w i c z L., 1980. Khimicheskoe regulirovanie zavyazivaniya plodov tomatov i ikh rosta i sozrevaniya. Primienienie Regulatorov Rosta. Mezhdunarodni i Simpozium w Rostoke 1978. Tag.-Ber. Akad. Landwirtsch. Wiss. DDR, Berlin 179: 195- 201. 
I w a h or i S., L y o n s J. M., 1970. Maturation and quality of tomatoes with preharvest treatments of 2-chloroethylphoshonic acid. J. Amer. Soc. Hort. Sci. 95: 88 - 91.

K e p k o w a A., 1959. Efektywność kilku różnych związków chemicznych i preparatów zastosowanych do hormonizowania pomidorów szklarniowych i wczesnych gruntowych. [A comparison of the effectivity of several chemical compounds and preparations used as hormone addition to hothouse and early field tomatoes]. Biul. Warz. 4: $305-323$.

K ę p k o w a A., 1968. Wpływ hormonizacji na zawiązywanie i wzrost oraz plon pomidorów szklarniowych. Praca habilitacyjna w SGGW - AR. Instytut Warzywnictwa, Skierniewice.

K e p k ow a A., G r a j e w s k a H., 1972. Substancje chemiczne w produkcji wczesnych pomidorów gruntowych. [Chemical substances in early outdoor tomatoes production]. Ogrodnictwo 7: $201-203$.

L e d ovsk i i S. Ja., 1974. Izmenenie vodnogo rezhima i produktivnosti rastenii tomata pod vliyaniem khlorkholinkhlorida. Ovoshchivnitstvo i bashtarnitstvo 17: 86-91.

L e d o v s k i i S. Ja., 1977. Vliyanie CCC na kachestvo rassady i rannil urozhai tomatov. Nauch. Tekhn. Biul. Ukr. NII Ovoshchevodstva i Bakhchevodstva 4: 33-35.

M i s h a r a B., P r a d h a n G. C., 1972. Effect of transpiration-reducing chemicals on growth, flowering and stomatal opening of tomato plants. Plant Physiol. 50: 271 - 274.

O s t r z y c k a J., B or k o w s k i J., 1982. Residues of chlormequat (CCC) in fruits and other parts of tomato plant after treating the seedlings with ${ }^{14} \mathrm{C}$-CCC. Acta Agrobot. 35, 1: $31-42$.

P i s a r c z y k J. M., S p $1 \mathrm{t} t \mathrm{~s} t$ o e s s e $\mathrm{r}$ W., 1979. Controlling tomato transplant height with chlormequat, daminoside and ethephon. J. Amer. Soc. Hort. Sci. 104: 342 - 343.

$\mathrm{S}$ i $\mathrm{m} \mathrm{s}$ W. L., 1969. Effects of Ethrel on fruit ripening of tomatoes, greenhouse, field and postharvest trials.' California Agriculture 23: $12-14$.

S i m s W. L., K a s h m i r e R. F., 1972. Ethephon response favorable on fresh marked tomatoes. California Agriculture 26: 3 - 4 .

S h u 1 g i n a L. M., 1977. Vliyanie khlokholinkhlorida i povishennikh temperatur vozdukha na kachestvo rassady i urozhainost tomata. Nauch. Tekh. Biul. Ukr. N. I. I. Ovoshchevodstva i Bakhchevodstva. 5: 33 - 36. (Ref. Zhurn. 1978, 3, 55. 314).

\section{Wplyw chlorku chlormekwatu, kwasu $\beta$-naftoksyoctowego i etefonu na plon wczesny i ogólny pomidorów gruntowych}

\section{Streszczen i e}

Rozsada pomidorów w inspekcie była opryskiwana dwukrotnie roztworem preparatu Antywylegacz (chlorek chlormek watu) w stężeniu $125 \mathrm{mg} / 1$. Po wysadzeniu do gruntu kwitnące 1-sze i 2-gie grona pomidorów traktowano Betoksonem (kwas $\beta$-naftoksyoctowy), a gdy zapalały się pierwsze owoce, w celu przyśpieszenia dojrzewania opryskiwano je preparatem Ethrel (etefon) w stężeniu $1 \mathrm{~cm}^{3} / 1$.

Doświadczenie prowadzono przez trzy lata, głównie na odmianie 'New Yorker' i 'Venture'. Chlorek chlormekwatu hamował wybieganie rozsady, lecz tylko nieznacznie zwiększał plon wczesny. Betokson w każdym roku bardzo istotnie zwiększal plon wczesny, zmniejszając jednocześnie plon ogólny. Chlorek chlormekwatu i kwas $\beta$-naftoksyoctowy zastosowane jednocześnie bardziej zwiększyły plon wczesny niż sam Betokson. Ethrel zastosowany razem z chlormekwatem i kwasem $\beta$-naftoksyoctowym spowodował dalszą nieznaczną zwyżkę plonu wczesnego. Sam etefon nie dzialał skutecznie $z$ powodu zbyt niskich temperatur panujących podczas opryskiwania. 